This item was submitted to Loughborough's Research Repository by the author.

Items in Figshare are protected by copyright, with all rights reserved, unless otherwise indicated.

\title{
Framing city networks through temporary projects: (trans)national film production beyond 'Global Hollywood'
}

PLEASE CITE THE PUBLISHED VERSION

https://doi.org/10.1177/0042098018790735

\section{PUBLISHER}

Sage (@ Urban Studies Journal Limited)

VERSION

AM (Accepted Manuscript)

\section{PUBLISHER STATEMENT}

This work is made available according to the conditions of the Creative Commons Attribution-NonCommercialNoDerivatives 4.0 International (CC BY-NC-ND 4.0) licence. Full details of this licence are available at: https://creativecommons.org/licenses/by-nc-nd/4.0/

\section{LICENCE}

CC BY-NC-ND 4.0

\section{REPOSITORY RECORD}

Hoyler, Michael, and Allan Watson. 2018. "Framing City Networks Through Temporary Projects: (trans)national Film Production Beyond 'global Hollywood'”. Loughborough University. https://hdl.handle.net/2134/33905. 


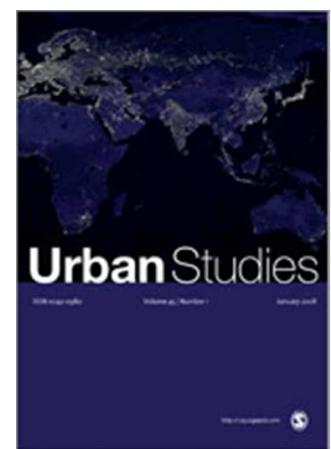

\section{Framing city networks through temporary projects: (trans)national film production beyond 'Global Hollywood'}

\begin{tabular}{|c|c|}
\hline Journal: & Urban Studies \\
\hline Manuscript ID & CUS-785-17-09.R2 \\
\hline Manuscript Type: & Article \\
\hline $\begin{array}{l}<\mathrm{b}>\text { Discipline: Please select a } \\
\text { keyword from the following list } \\
\text { that best describes the } \\
\text { discipline used in your paper.: }\end{array}$ & Geography \\
\hline $\begin{array}{r}\text { World Region: Please select } \\
\text { the region(s) that best reflect } \\
\text { the focus of your paper. } \\
\text { Names of individual countries, } \\
\text { cities \& economic groupings } \\
\text { should appear in the title } \\
\text { where appropriate.: }\end{array}$ & Not Applicable \\
\hline $\begin{array}{l}\text { Major Topic: Please identify up } \\
\text { to } 5 \text { topics that best identify } \\
\text { the subject of your article.: }\end{array}$ & Globalisation, Networks, Culture/Arts/Creativity \\
\hline $\begin{array}{l}\text { You may add up to } 2 \text { further } \\
\text { relevant keywords of your } \\
\text { choosing below: }\end{array}$ & film production, social network analysis \\
\hline
\end{tabular}

\section{SCHOLARONE \\ Manuscripts}




\title{
Framing city networks through temporary projects: (trans)national film production beyond 'Global Hollywood'
}

\begin{abstract}
This paper advances research on external urban relations by drawing attention to the role of temporary project-based economic organisation in the formation of inter-firm links between cities. Through a novel empirical examination of (trans)national co-production in the motion picture industry, we reveal how such projects transcend the boundaries of individual production clusters and link urban centres within specific network configurations. Stripping away the 'top layer' of Hollywood's commercially successful feature films, we undertake a social network analysis of film productions in four markets across three continents - China, Germany, France and Brazil - to provide a unique comparative analysis of networked urban geographies. Our findings show that film production networks are grounded in existing structural relations between cities. The spatial forms of these networks range from monocentric in the case of the French film market, to dyadic in the case of China and Brazil, to polycentric in the case of the German film market. Conceptually, we argue that adopting an inter-firm project-based approach can account for the ways in which complex patterns of inter-firm production relations accumulate to form (trans)national city-networks. Viewing city networks in this way provides an important alternative perspective to dominant conceptualisations of global urban networks as formed through corporate intrafirm relations.
\end{abstract}

\section{Keywords}

Globalisation, Networks, Culture, Arts, Creativity, Film Production, Social Network Analysis 


\section{Introduction}

Because of the success of the US film industry, there has quite simply been a dearth of studies looking beyond Hollywood... if globalization is a process of emerging global networks, we need to know more about these networks. (Lorenzen, 2007: 354, emphasis added)

Conceptualising and empirically investigating multifarious networks across a range of scales has been at the heart of intellectual endeavours which seek to make sense of globalisation. One prominent strand in this literature has been the study of the "world city network' (Taylor and Derudder, 2016) to capture the increased connectivity between cities in economic globalisation. Empirically, this research has been centred on an interlocking network model for measuring the connectivities of cities. The central tenet of this model is that intra-firm networks of advanced producers services (APS) firms, and other firms with worldwide reach, for example global media corporations (Hoyler and Watson, 2013) can serve as a proxy for both embodied and virtual flows that link city economies across space.

While this approach has successfully modelled and mapped the networked urban geographies of APS, in other sectors, such as the creative and new media industries, the development of more flexible and project-based economic organisation has challenged the centrality of large firms (Grabher, 2002). In particular, we argue that traditional intra-firm approaches fail to adequately capture how these complex yet temporary organisational configurations translate into enduring patterns of relations between cities. Our aim in this paper is to draw attention to the role of project-based inter-firm economic organisation in the formation of relational networks between cities. To do so, we undertake a novel study of (trans)national co-production in the motion picture industry, part of a wider set of creative industries which are characterised, perhaps more than any other industrial sector, by project-based work. Focusing on the network-building capacity of temporary inter-firm projects, we complement and extend, both conceptually and methodologically, existing studies of global urban networks as formed through corporate intra-firm relations.

Geographical research into the film industry has tended to focus on the internal dynamics of individual clusters of film production, or at the other end of the scale on the ongoing 
globalisation of the film industry, in particular on 'Global Hollywood' (Miller et al., 2001), 'Global Bollywood' (Kavoori and Punathambekar, 2008) and 'Global Nollywood' (Miller, 2012). A smaller number of studies have considered the growing phenomenon of international co-productions (see Lorenzen, 2007; Morawetz et al., 2007) as filmmakers cross borders in search of co-producers, finance, labour, subsidies and film locations (Goldsmith and O'Regan, 2008). However, attention has yet to be given to the emerging networked geographies of these co-productions. This is a significant omission because, as Mossig (2008) notes, the trading of creative content, capital and talent bridges the physical gaps between urban clusters of film production companies across the globe (see for example Cole, 2008). Thus we see production companies in film as potentially important urban network makers.

Stripping away the top layer of Hollywood's commercially successful feature films, we reveal the emerging relational geographies of co-production centred on other key urban concentrations of film production. Following Crane (2014), our case studies consist of four non-Anglophone markets with established cinematic traditions of feature film production: one emerging 'super producer', China; two 'major producers', France and Germany; and one 'medium producer', Brazil. We employ a social network analysis to 1) map the structure of city networks emerging from connections between film production firms within and across territorial boundaries; 2) identify centrality and community structures in each network through the application of specific network measures, and 3) distinguish contrasting urban constellations of film production networks. We highlight the implications of a project-based approach to inter-city networks for conceptualisations of the world city network.

\section{The economic geography of the global film industry}

There exists a longstanding interest in film production amongst economic geographers. In their seminal analysis of vertical disintegration in the motion picture industry, Christopherson and Storper (1986) highlighted the 'dramatic transformation' of the film industry from one traditionally dominated by large vertically integrated firms, to one in which production is primarily carried out by smaller, independent production companies, which subcontract production activity to small specialised firms. They described how this 
has resulted in a horizontally integrated transactions-intensive industry, in which producing film is a complex process involving non-standardised and small-scale input-output relations between firms.

Yet, as Christopherson (2013) describes, the development of the two-stage model - the 'studio system' and vertical disintegration - is a relatively simplistic representation of the relationship between content production and distribution. Although film production has become vertically disintegrated, there has been significant concentration in film distribution. The result, she suggests, is the major distribution channels resting under the control of a vertically integrated media oligopoly. Under concentrated media distribution, there is an emphasis on 'blockbuster' movies and a reluctance to invest in riskier projects, leading to increased divergence between blockbusters and an independent film sector making much lower budget movies (Christopherson and Rightor, 2010).

Thus US media conglomerates have continued to thrive in the emerging global media market (Christopherson, 2013), resulting in the locking of the world's pre-eminent film production complex within Los Angeles. Yet, as Scott (2002: 972) points out, 'new and revivified cultural-products agglomerations are on the rise in many different parts of the world'. These include the Munich feature film cluster in Germany (Zademach, 2009), the Potsdam/Babelsberg film industry, also in Germany (Krätke, 2002); the indigenous film industry of Vancouver, Canada (Coe, 2001); regional film production centres in North America (Foster et al., 2015); Hong Kong's film industry (Kong, 2005), and Sydney’s film and television cluster (O'Regan et al., 2011). Film export patterns are becoming increasingly complex and dense, involving film producers elsewhere in the world (Chung, 2011; Lorenzen, 2007).

\section{Theorising co-productions within city networks}

Film production in a horizontally integrated transactions-intensive industry is characterised by project-based organisation in the form of co-productions. Following Manning and Sydow (2007) we consider co-production projects as 'temporary systems' of production involving a range of firms, creative artists and technical services, with actors drawn from established pools of talent in project networks as 'more than temporary systems'. These 
pools are 'quasi-external', 'merge into the market' and are 'network-specific', in that they match with the particular demands of content creators and producers. In addition, Manning and Sydow (2007: 24) argue that the reproduction of project networks must be situated within organisational fields, which they contend are regionally embedded, and which contain 'deeply institutionalized industry practices', as well as local market conditions, regional institutions and support networks.

Perspectives regarding the regionally-embedded nature of project networks and organisational fields are, however, progressively being challenged by 'the increasing trend to international co-productions' (Scott, 2002: 972). Morawetz et al. (2007: 421) suggest that international productions are a 'growing phenomenon', while Lorenzen (2007: 353) notes that 'cross-border co-productions have been around for a century, but are experiencing a recent boom'. International collaboration is common not only in highbudget productions, but is also 'a normal practice for film makers' in lower-budget and independent productions (Goldsmith and O’Regan, 2008: 13).

As Morawetz et al. (2007) highlight, cross-border work may take place for a variety of reasons. These include creative, technical and market-specific objectives, for example, to take advantage of particular expert skills, to access locally embedded resources, and to tap into existing local inter-organisational networks (Sydow et al., 2010). They also include financial reasons, such as in co-productions where financial resources are pooled; or where there are local or national tax incentives and other financial support for film making, including state subsidies for national filmmakers (see for example Jansen, 2005, on Germany); or to attract film producers from elsewhere (see Christopherson and Rightor, 2010, on the US).

Co-productions create (trans)national film project networks as mechanisms for managing resource interdependencies, within and across countries and national contexts, and bridge the physical gaps between urban clusters of film production. In this way, cities are central to media and cultural production, not only because of the clusters of creative and economic activity contained within them, but also through the networks formed between firms across these clusters. In project-based industries such as media, film and music, networks between 
cities represent an accumulation of project networks, each embedded within and across local, regional and national organisational fields.

As highlighted earlier with reference to the interlocking network model, the dominant approach to the empirical study of world city networks has been to examine the intra-firm networks of major corporations. However, approaching the study of a vertically disintegrated industry such as film production from an intra-firm perspective is problematic. This is due to the way in which film production projects take place 'in the market', that is to say that participating skill holders are employed in different firms or are freelancers, and as such projects transcend the boundaries of firms (Lorenzen and Frederiksen, 2005). The role of firms within these project networks is primarily to organise these external resources into multi-disciplinary teams to accomplish specified tasks and to finance and distribute films (Ferriani et al., 2005). Furthermore, these firms, like projects, often represent only temporary organisational configurations. Often created for a limited time and purpose, firms may cease to exist when a project has been completed as part of 'a continuous process of organizational formation and dissolution' (Baker and Faulkner, 1991: 283). Thus an approach focused on the internal resources and organisations of 'stable' firms is unable to capture the complexity of film production networks.

In this paper we undertake an analysis of relational urban networks of film production that seeks not only to understand how film co-productions transcend the boundaries of individual firms and clusters and link together urban centres of production in temporary project networks, but which also makes a conceptual advance to current analyses of world city networks. Through adopting a project-based inter-firm approach to network analysis, rather than an intra-firm approach, we are able to theoretically and methodologically account for the complexities of the relational networks formed between firms in cities through project work.

\section{Methodology}

\section{Data collection}

The website Box Office Mojo (www.boxofficemojo.com) provided information on the top grossing films in 2013 and 2014. We recorded the top 200 grossing films in each year for 
each selected country where available to provide a cross-sectional dataset of sufficient size (the total number of films listed for China was 164 in 2013 and 167 in 2014). Each film represents its own temporary project, consisting of a variety of inter-firm ties including production, post-production and finance, with each project having its own distinct production network, varyingly dispersed in terms of its geography. In collecting data for the social network analysis, we employed a project-based strategy in which network boundaries are drawn by including firms who participate within these projects (see also Watson, 2012). This was achieved by tracking each film in the Internet Movie Database (IMDb, www.imdb.com) to identify all production companies engaged in its making. We did not include distribution companies; companies involved in other supporting activities such as sound production, equipment hire, catering etc.; or regional or national funding agencies providing subsidies for particular filming locations. While IMDb provides a readilyavailable source of such data, there are a number of limitations that must be recognised. First, IMDb listings rely on self-reporting from film production companies and film studios, and therefore not all participating companies may be included for a given film. Second, it is not possible in most cases to differentiate between the different roles (e.g. production, post-production, financial) played by a production company within a project.

For each production company, further desktop research was conducted to identify the office location(s) involved in the production of a film, utilising specialised websites such as filmportal.de (Germany) and cineuropa.org (France), individual production company websites and general business directories (such as societe.com). All films which were (co)produced by at least one 'nationally-based' production company were included in our study, while major Hollywood-produced commercial films and other highly successful films not involving at least one production firm located in the home territory were excluded from further analysis.

Table 1 further breaks down these data into co-productions that cross national boundaries ('transnational') and co-productions across multiple cities within a single territory ('national'). These two categories form the basis of our network analysis, which we combine as '(trans)national' film productions. The involvement of production companies with a home base in the respective national market is highest in France (41\%), reflecting the distinctive history and tradition of French cinema, but is much lower in the emerging 


\begin{abstract}
Latin-American market of Brazil (12\%), where the success of non-national productions dwarfs the contribution of film projects with Brazilian participation.
\end{abstract}

[Insert Table 1 here]

In addition, we recorded data on single and multiple-firm productions located within a single city. Their share of total productions varies considerably from a low $13 \%$ in Germany to above $40 \%$ in all other markets analysed (Table 1). This reflects the highly variable dispersion/concentration of film production companies across the different national urban systems - at the extremes, German production companies were located across 19 cities in the country, whereas French production companies were overwhelmingly located in the Paris metropolitan region. These local (co-)productions are not included in our network analysis but form part of the contextual interpretation of our findings.

For each of the markets, we initially constructed a two-mode firm-by-project matrix, recording all production companies involved in multilocational (trans)national film productions. As with the interlocking network model, we apply a bipartite projection function that infers a network from non-network data and transforms a two-mode network into a one-mode network (see Neal, 2014). However while the interlocking network model applies an intra-firm strategy that assumes that the presence of a single (APS) firm across cities implies connectivity, here we apply an inter-firm strategy that assumes that copresence of film production firms in a project implies connectivity. While in reality different firms take on different roles in projects, and not every firm in a project will interact with every other, we take the co-presence of firms within the same projects as opening up the potential for interaction, and therefore as being a relatively robust empirical proxy for the myriad of financial, creative and embodied flows occurring between firms across cities. Thus we develop a similar set of assumptions as those associated with the bipartite projection used in the interlocking network model.

As with the interlocking network model, connections in the two-mode matrix (edges) are non-directional. However, unlike the interlocking network model, edges are binary and not valued, indicating the presence (1) or absence (0) of any given firm in a particular project. We therefore assume that all firms that are part of project-based production networks are 
connected to each other with links of the same intensity and value. Given our data, it was not possible to identify any particular links as being more important to the completion of a project than other links in a systematic and consistent manner. It is important to recognise this as a limitation of our data collection strategy as it is typical in film production projects for one firm to co-ordinate activities on a project, and therefore some links will have greater intensity and/or value than other links.

The two-mode firm-by-project matrices for each territory were transposed into one-mode firm-by-firm matrices based on the assumption that every firm in a project interacts with every other firm in a form of group participation. Firm-to-firm links within a project were then translated into city-to-city links based on company location. Thus a link between two cities represents that the production of a film involved both a firm located in the first city and a firm located in the second city. The strength of connectivity between any two cities is determined by the number of projects that share partners across the two cities.

Four symmetrical city-by-city matrices were produced of varying sizes; a $55 \times 55$ cities matrix for the German film market; a 42x42 cities matrix for the French film market; a $22 \times 22$ cities matrix for the Chinese film market; and a 12x12 cities matrix for the Brazilian film market. These matrices form the input to the social network analysis reported in the following section.

\section{Social Network Analysis}

The social network analysis was undertaken using the UCINET software, while network visualisations were derived through the Gephi network visualisation software. We employ a degree centrality measure to assess the role and position of cities within urban film production networks. Centrality refers to a position within a network that affords actors and firms within a city the ability to interact with other cities throughout the world (Neal, 2013). Specifically, we employ Freeman's degree centrality measure, the basic premise of which is that a node is important if it has many neighbours. In this case, as the data matrix is not directed, the measure provides a single value of centrality, with actors differing from one another only in how many connections they have (Hanneman and Riddle, 2005).

Centrality is a characteristic of cities that derives from distinct structural patterns of linkages. With degree centrality, it is assumed that actors who have more ties to other 
actors may be in advantaged positions: because they have many ties, they may have access to, and be able to call on more of the resources of the network as a whole (Hanneman and Riddle, 2005). Given that we use a bipartite projection, the outcomes of this measure need some careful interpretation. With specific regard to our analysis of film co-productions, we take a high level of degree centrality for a given city as indicating the extent to which production companies in the city have partnered with production companies in other cities, and therefore the extent they have been able to call on resources that exist in networks of film production beyond their own location.

To further understand these networks, we also employed the community detection facility in Gephi. Based on the Louvain modularity method (see Blondel et al., 2008), this seeks to extract the community structure of large networks, by partitioning a network into communities of densely connected nodes, with the nodes belonging to different communities being only sparsely connected. The default resolution parameter of 1.0 was used. We employed the partition module within Gephi to visualise these communities.

\section{Networks of film production beyond Hollywood}

\section{China}

China - the world's second largest film market in terms of box-office receipts behind the United States - is in many ways a unique case study due to the political context in which Chinese cultural production takes place. In 1994, 45 years of restriction ended with selected foreign movies being officially allowed into Chinese theatres. Chu (2010) suggests that this policy change was due to a collapse in the domestic film market, with Hollywood characterised as a panacea to rescue the film industry. By the mid-2000s, the Chinese film industry had recovered, increasing film production from 260 Chinese feature films in 2005 to 638 films in 2013 (UIS, 2016: 9). This makes China the world's third-largest film production centre behind only India and the US (UIS, 2016), with domestic films garnering over 50 per cent of China's box office since 2009 (Yeh, 2014). Further, through the early 2000s, a number of Chinese-language films achieved global box office success, radically altering the landscape of Asian film making (Klein, 2007). However, within China, there remains significant state control over the distribution of films: the China Film Group based 
in Beijing - the largest and most influential state-run film enterprise in China - acts as a powerful gatekeeper in terms of the distribution and censorship of foreign films (Curtin, 2016; Yeh and Davis, 2008).

Of the 331 films listed in our data, almost a third involved Chinese production companies. Of these 111 films, 67 (60\%) were produced by one or more firms (co-)located in a single city, predominantly Beijing and Hong Kong. More significant with regard to our study however are the 44 productions that link cities together, both within and beyond China. Figure 1 shows a network diagram that consolidates all networked productions involving Chinese firms. Displayed prominently is the Beijing-Hong Kong dyad with over six times the number of connections between them - that is to say, there are six times more projects that share partners across the two cities - than between any other pair of cities in the network. Out of 44 networked films, 26 involved firms in both Beijing and Hong Kong, 16 of which did not involve companies outside the two cities. Klein (2007: 189) refers to this as the 'strategic enmeshment' of the Hong Kong and mainland Chinese film industries, creating mutually beneficial flows of capital, modes of production, stylistic conventions and expertise.

\section{[Insert Figure 1 here]}

Beijing is connected to every other city in the network (bar one). The structural position of Beijing within the network is in part an outcome of state involvement in film production; just under one quarter (24) of the 111 Chinese (co-)productions in our data involved the China Film Group Corporation. However, the fact that eleven out of a total of 22 cities within the network are located outside China, suggests that the Chinese film industry is far from insular. Indeed, Klein (2007: 189) argues that Chinese cinema is 'inescapably transnational', while Yeh and Davis (2008: 38) note that 'China's screen industry has accelerated its transnational activities in co-productions and joint ventures absorbing outside investment in infrastructure'.

[Insert Table 2 here] 
Table 2 illustrates through the results of the degree centrality analysis how China's capital city Beijing occupies a dominant role as the most central node in film production for the Chinese market (see also Zhang and Li, 2018). Hong Kong is second, suggesting a significant role, but yet one that is very much defined by its relationship with Beijing. Tokyo and New York jointly occupy third position, but both are significantly behind the two leading cities by degree centrality. The presence of New York, along with that of Los Angeles in fifth, highlights the key role of US production companies in providing supporting expertise and capital to Chinese film production networks. Shenzhen is positioned in sixth closely behind the two US cities.

Community analysis (Figure 1) shows a main community (dark grey) consisting of Beijing, Hong Kong, and all other Chinese cities, as well as a number of non-Chinese cities including Los Angeles and Seoul. Within the network there also exists a sub-community (light grey) of non-Chinese cities that consists of New York, Tokyo, London, Vancouver and San Francisco.

\section{Germany}

As Jansen (2005) explains, the German film industry has grown against a background of heavy public funding, despite German film only capturing a small domestic market share. Jansen highlights how financial support has traditionally come mainly from federal and state governments, with additional money provided by public and private TV stations at the federal and state level. Since the 1990s, Halle (2006) argues, the industry has seen a shift from a primarily state-subsidised system to a market-orientated popular cultural entertainment system, a change that has taken place within larger processes of globalisation, and which has seen Hollywood majors open affiliates in Germany.

\section{[Insert Figure 2 here]}

In our data for 2013/14, of 400 films sampled for the German market, 102 (25\%) involved German production companies, placing it significantly behind France and China for national involvement in its own film market. Of these 102 films, 39 (38\%) were transnational multi-city productions. Further, they are also highly networked at the national 
level, with almost half (50) of our sample consisting of national multi-city productions. Figure 2 displays the urban networks formed through these productions. Of our four case studies, this is the largest network, containing 55 cities in total, and with 33 of these cities outside Germany. A group of highly-connected German cities is evident: Munich, Berlin, Cologne, Frankfurt, Hamburg and Baden-Baden. This reflects Germany's historically polycentric urban system, with economic functions widely distributed across a range of large and medium-sized cities (Hoyler, 2011). Paris is the most well-connected of the nonGerman cities, but has less than one third of the total number of connections of the most connected city, Munich.

Degree centrality measures for the German production network show German cities occupying the top six places (Table 2). Munich is a clear first, and Berlin second, followed by Cologne, Frankfurt, Hamburg and Baden-Baden. Unlike the Chinese network which is dominated by just two cities, the total degree value within the German network is more evenly shared. These six major cities, as well as a range of medium-sized and smaller cities, are seats of regional, national or transnational television stations, such as Baden-Baden (Arte) or Mainz (ZDF), which co-produce a significant number of nationally successful films. Inter-city relationships in film production in Germany are therefore not focused on a single city or one dyadic relationship but are highly polycentric, including a range of international locations.

Community analysis (Figure 2) shows a main community (dark grey) consisting of the five major cities and many other small German and international production centres. Two smaller sub-communities also exist within the network (light grey). The first and largest of these represents an Anglophone-focused network that includes London, Los Angeles and New York, and a number of other small international production centres, as well as the major German film production centre of Potsdam. Potsdam is characterised more by its high level of links to the Hollywood film cluster than its links to German production centres (Krätke, 2002), and hence does not have a high degree centrality in our network based upon German film productions. This sub-community is tied into the German network mainly through links between Munich, London, and Los Angeles, the latter two of which act as gateways into international production networks. 


\section{France}

France is the largest European producer of films (Crane, 2014) and the largest market for film by box office revenues in Europe. Jäckel (2007) describes how French film has often been seen as an alternative to the dominant Hollywood model, owing its cultural specificity (a focus on auteur films) to 'the strong regulatory framework and comprehensive, sophisticated support system that France has developed over the years' (2007: 21). Yet, Vanderschelden (2007) notes that the inflation of budgets for popular films has forced French film producers to seek co-operation across borders in order to access foreign markets and funds.

In our data for 2013/14, of the 400 films sampled for the French market, 165 (41\%) involved French production companies, making it the film market with the most national involvement in film production of our case studies. Of these 165 films, almost half (81) are international multi-city productions, the highest share in our case studies. Yet $45 \%$ (75) are national single-city productions, all of which were produced in Paris. In fact, every film in our data produced in France involved at least one company located in Paris. Thus our data suggests that film production in France is highly localised within the capital (Figure 3).

The network is the second largest of our case studies, containing 42 cities. Of note is that 39 of these cities are outside France. Paris is connected to every other city in the network and has double the number of connections - that is to say, shared project links with other cities - compared with the second ranked city, Brussels. The nature of the globalised production networks formed by firms in France could be seen as reflecting a legacy of protectionism; links between French production firms and firms in other cities are numerous, yet generally weak. The exception - and a good example for the influence of state policy on the formation of urban networks - is the strong tie with Brussels, indicative of the favourable tax incentives ('tax shelter') available for international co-productions with Belgian participation (Mundell, 2012).

Analysis of degree centrality for the French production network confirms the dominance of Paris, having a significantly higher share of the total degree value of the network than any other city (Table 2). This reflects the city's historical prime position in the French urban 
system. Brussels is second to Paris. Brussels is a city through which productions must go in order to take advantage of financial incentives, and as such it is highly dependent on its links with Paris for its network centrality. London is placed third but far behind Brussels and Paris. Luxembourg, Los Angeles and Lyon also feature in the top six cities.

[Insert Figure 3 here]

Community analysis (Figure 3) shows a dominant main community (dark grey) consisting of the majority of the production centres in the network and two smaller sub-communities (light grey) centred on Canada (Toronto, Montreal) and Switzerland (Geneva, Bern) respectively. These represent links between the dominant French-language network centred on Paris, and minor French-language production communities in these two countries.

\section{Brazil}

Recent academic work on Brazilian film (Brannon Donoghue, 2014) has pointed towards a revival of the country's film industry that began in the mid-1990s and strengthened through the 2000s. Yet, our investigation suggests that Brazilian films have limited box-office success. In our sample of 400 top-grossing films in Brazil, just 49 (12\%) were produced within Brazil; as Martinez (2008, no pagination) argues, 'the overpowering presence of Hollywood in the market' remains a key issue. Thus national film policy would seem to have been ineffectual in challenging US dominance in its own national film markets, whilst free-trade agreements have resulted in declining national shares of the domestic film market (Crane, 2014).

Further, national film policies make the dependence of the Brazilian film industry on state regulation and support problematic. Of particular note here is the role of the Globo network, Brazil's media hegemon emerging from a legacy of the corporation's role in promoting the ideological agendas of Brazilian military regimes through the 1960s and 1970s. In our data, the corporation's film division Globo Filmes was involved in 53\% of Brazilian productions. This goes some way in supporting the assertion of Dos Santos (2009) that any revival in Brazilian film can in significant part be seen as an attempt of the Globo corporation to further strengthen its control over national media markets. Further, 
Brannon Donoghue (2014) describes the rise of the 'Brazilian Blockbuster' as Brazilian firms such as Globo adapt globalised production models of scope and scale.

Yet, while Brannon Donoghue (2014) talks of increased transnational partnerships in Brazilian film, of our four case studies Brazil has the second least internationalised production network. Again our data point to the role of Grupo Globo: of the 26 productions involving Globo Filmes, just seven are international, suggesting that the corporation has a strong effect in locking film production within Brazil. More widely, of the 49 films with Brazilian production involvement, 20 are based in a single Brazilian city, while 17 are coproduced within national city networks, and only 12 involve both Brazilian and international cities. The urban network formed by these productions is the most limited of our case studies in terms of number of cities in the network; it consists of just twelve cities, only half of which are outside Brazil.

\section{[Insert Figure 4 here]}

The dominant Rio de Janeiro-São Paulo dyad (Figure 4) is reflected in the centrality analysis (Table 2). The two cities have an equal share of the overall degree value of the network. This indicates a truly dyadic relationship between the two centres in terms of film production, and this dyad forms the core first-tier of the network. Los Angeles is positioned third, reflecting the influence of Hollywood on localised film production and consumption. Yet it is notable that Los Angeles does not act as a gateway for Brazilian film producers into wider international production networks. This is highlighted through the community analysis (Figure 4), which places Los Angeles in a separate sub-community to an already limited main community (dark grey) that contains the Rio de Janeiro-São Paulo dyad, and in which Madrid and Buenos Aires also feature strongly.

\section{Conclusions}

In this paper, we have undertaken an examination of the relational urban networks created through project-based co-productions between film production firms within and across national film production clusters. Focusing on the networked urban geographies of four national film markets in three continents - China, Germany, France and Brazil - we have 
identified the emerging relational geographies of co-production centred on urban concentrations outside of the dominant Hollywood cluster. Our findings show that film production networks are grounded in existing structural relations between cities within each country. The spatial forms of these networks range from monocentric in the case of France, to dyadic in the case of China and Brazil, to polycentric in the case of Germany, not dissimilar to the structure of their national APS networks (Taylor et al., 2011) but with sectoral specificities. Film production therefore, like APS, is bound up in long-established historical patterns of urban development and reflects the dispersal of economic, cultural and political functions across national territories as much as the organisational logics of film production.

Beyond national urban constellations, the 'strategic enmeshment' (Klein, 2007) arising from co-productions creates external relations between cities across different territories. While the most central cities in each of the networks are shown to be one or more major national production centres, Los Angeles features prominently in all of the networks and one or more of an established group of film production centres, consisting of New York, London, Tokyo and Paris, appear in all four networks. Firms within these cities act to link national production networks with broader external networks. This is evidenced through community analysis. In the case of Germany, for example, firms in London, Los Angeles and Paris provide opportunities for co-productions with Anglophone and French film production companies respectively.

In this paper, we have sought to complement and extend research on the world city network. Conceptually, we have argued that adopting an inter-firm project-based approach capturing temporary organisational configurations (in this case, film co-productions) as a complementary strategy to the intra-firm-based approach more typical in research on the world city network, can account for the ways in which complex patterns of inter-city production relations accumulate to form more enduring relational networks between cities. In other words, it is an approach which seeks to reveal how 'specific, grounded choices that are iterated many times' result in 'complex structures with significant and enduring outcomes' (Curtin, 2016: 68). Methodologically, we have applied a bipartite function to two-mode inter-firm project-based data in order to infer one-mode firm-to-firm connections. Applying social network analysis to a resulting city-by-city matrix of 
connections based upon firm location has allowed us to identify the structural positions of particular cities, and by proxy, local urban concentrations of film production activity, within these networks. Given the prevalence of project-based organisation within the global economy, there would seem to be a pressing need for new conceptual and methodological advances to the study of city networks, and the wide range of different sectors of economic activity that constitute these networks.

\section{Acknowledgements}

Earlier versions of this paper were presented at the Doing Global Urban Research international conference, held at Loughborough University in September 2015 and at the RGS-IBG Annual International Conference 2016 in London. We are grateful to the participants for their constructive feedback. We would also like to thank John Harrison and three anonymous referees for their insightful and supportive comments.

\section{References}

Baker WE and Faulkner RR (1991) Role as resource in the Hollywood film industry. American Journal of Sociology 97(2): 279-309.

Blondel VD, Guillaume J-L, Lambiotte R and Lefebvre E (2008) Fast unfolding of communities in large networks. Journal of Statistical Mechanics: Theory and Experiment (10): P10008.

Brannon Donoghue C (2014) The rise of the Brazilian blockbuster: how ideas of exceptionality and scale shape a booming cinema. Media, Culture \& Society 36(4): 536-550.

Christopherson S (2013) Hollywood in decline? US film and television producers beyond the era of fiscal crisis. Cambridge Journal of Regions, Economy and Society 6(1): 141-157.

Christopherson S and Rightor N (2010) The creative economy as 'big business': evaluating state strategies to lure filmmakers. Journal of Planning Education and Research 29(3): 336-352. 
Christopherson S and Storper M (1986) The city as studio; the world as back lot: The impact of vertical disintegration on the location of the motion picture industry. Environment and Planning D: Society and Space 4(3): 305-320.

Chu KKL (2010) Co-opting the wolves: National film industry reform in China after 1978. Asian Politics \& Policy 2(1): 95-121.

Chung JE (2011) Mapping international film trade: network analysis of international film trade between 1996 and 2004. Journal of Communication 61(4): 618-640.

Coe NM (2001) A hybrid agglomeration? The development of a satellite-Marshallian industrial district in Vancouver's film industry. Urban Studies 38(10): 1753-1775.

Cole A (2008) Distant neighbours: The new geography of animated film production in Europe. Regional Studies 42(6): 891-904.

Crane D (2014) Cultural globalization and the dominance of the American film industry: cultural policies, national film industries, and transnational film. International Journal of Cultural Policy 20(4): 365-382.

Curtin M (2016) What makes them willing collaborators? The global context of Chinese motion picture co-productions. Media International Australia 159(1): 63-72.

Dos Santos S (2009) The central role of broadcast television in Brazil's film industry: the economic, political, and social implications of global markets and national concentration. International Journal of Communication 3: 695-712.

Ferriani S, Corrado R and Boschetti C (2005) Organizational learning under organizational impermanence: collaborative ties in film project firms. Journal of Management and Governance 9: 257-285. 
Foster P, Manning S and Terkla D (2015) The rise of Hollywood East: regional film offices as intermediaries in film and television production clusters. Regional Studies 49(3): 433-450.

Goldsmith B and O'Regan T (2008) International film production: Interests and motivations. In: Wasko J and Emerson M (eds) Cross-Border Cultural Production: Economic Runaway of Globalization. Youngstown: Cambria Press, pp 13-44.

Grabher G (2002) The project ecology of advertising: tasks, talents and teams. Regional Studies 36(3): 245-263.

Halle R (2006) German film, European film: transnational production, distribution and reception. Screen 47(2): 251-259.

Hanneman RA and Riddle M (2005) Introduction to Social Network Methods. Riverside, CA: University of California. Available at http://faculty.ucr.edu/ hanneman/nettext/ (accessed 11 September 2017).

Hoyler M (2011) External relations of German cities through intra-firm networks - a global perspective. Raumforschung und Raumordnung 69(3): 147-159.

Hoyler M and Watson A (2013) Global media cities in transnational media networks. Tijdschrift voor Economische en Sociale Geografie 104(1): 90-108.

Jäckel A (2007) The inter/nationalism of French film policy. Modern \& Contemporary France 15(1): 21-36.

Jansen C (2005) The performance of German motion pictures, profits and subsidies: some empirical evidence. Journal of Cultural Economics 29(3): 191-212.

Kavoori AP and Punathambekar A (2008) Global Bollywood. New York: New York University Press. 
Klein C (2007) Kung Fu Hustle: Transnational production and the global Chinese-language film. Journal of Chinese Cinemas 1(3): 189-208.

Kong L (2005) The sociality of cultural industries: Hong Kong's cultural policy and film industry. International Journal of Cultural Policy 11(1): 61-76.

Krätke S (2002) Network analysis of production clusters: The Potsdam/Babelsberg film industry as an example. European Planning Studies 10(1): 27-54.

Lorenzen M (2007) Internationalization vs. globalization of the film industry. Industry and Innovation 41(4): 349-357.

Lorenzen M and Frederiksen L (2005) The management of projects and product experimentation: Examples from the music industry. European Management Review 2(3): 198-211.

Manning S and Sydow J (2007) Transforming creative potential in project networks: How TV movies are produced under network-based control. Critical Sociology 33(1-2): 19-42.

Martinez G (2008) Cinema law in Latin America: Brazil, Peru and Colombia. Jump Cut: A Review of Contemporary Media 50. Available at: http://www.ejumpcut.org/archive/jc50.2008/LAfilmLaw/ (accessed 26 August 2017).

Miller J (2012) Global Nollywood: The Nigerian movie industry and alternative global networks in production and distribution. Global Media and Communication 8(2): 117-133.

Miller T, Govil N, McMurria J and Maxwell R (2001) Global Hollywood. London: British Film Institute.

Morawetz N, Hardy J, Haslam C and Randle K (2007) Finance, policy and industrial dynamics The rise of co-productions in the film industry. Industry and Innovation 14(4): 421-443. 
Mossig I (2008) Global networks of the motion picture industry in Los Angeles/Hollywood using the example of their connections to the German market. European Planning Studies 16(1): 43-59.

Mundell I (2012) Belgium, Luxembourg \& Netherlands: incentives are burgeoning. Variety 18 May. Available at: http://variety.com/2012/film/markets-festivals/belgium-luxembourgnetherlands-incentives-are-burgeoning-1118053879/ (accessed 30 August 2017).

Neal ZP (2013) The Connected City: How Networks are Shaping the Modern Metropolis. New York: Routledge.

Neal ZP (2014) Validity in world city network measurements. Tijdschrift voor Economische en Sociale Geografie 105(4): 427-443.

O'Regan T, Goldsmith B and Ward S (2011) Sydney's media cluster: Continuity and change in film and television. In: Karlsson C and Picard RG (eds) Media Clusters: Spatial Agglomerations and Content Capabilities. Cheltenham: Edward Elgar, pp 199-222.

Scott AJ (2002) A new map of Hollywood: The production and distribution of American motion pictures. Regional Studies 36(9): 957-975.

Sydow J, Windeler A, Wirth C and Staber U (2010) Foreign market entry as network entry: A relational-structuration perspective on internationalization in television content production. Scandinavian Journal of Management 26(1): 13-24.

Taylor PJ and Derudder B (2016) World City Network: A Global Urban Analysis. 2nd ed. London: Routledge.

Taylor PJ, Ni P, Derudder B, Hoyler M, Huang J and Witlox F (eds) (2011) Global Urban Analysis: A Survey of Cities in Globalization. London: Earthscan.

UIS (2016) Diversity and the Film Industry: An Analysis of the 2014 UIS Survey on Feature Film Statistics. Montreal: UNESCO Institute for Statistics. 
Vanderschelden I (2007) Strategies for a 'transnational'/French popular cinema. Modern \& Contemporary France 15(1): 37-50.

Watson A (2012) The world according to iTunes: mapping urban networks of music production. Global Networks 12(4): 446-466.

Yeh EY (2014) Home is where Hollywood isn't: recasting East Asian film industries. Media Industries Journal 1(2): 59-64.

Yeh EY and Davis DW (2008) Re-nationalizing China's film industry: Case study on the China Film Group and film marketization. Journal of Chinese Cinemas 2(1): 37-51.

Yoon H (2017) Globalization of the animation industry: multi-scalar linkages of six animation production centers. International Journal of Cultural Policy 23(5): 634-651.

Zademach HM (2009) Global finance and the development of regional clusters: tracing paths in Munich's film and TV industry. Journal of Economic Geography 9(5): 697-722.

Zhang X and Li Y (2018) Concentration or deconcentration? Exploring the changing geographies of film production and consumption in China. Geoforum 88: 118-128. 
Table 1. Nationally-based film production in the top 200 in 2013 and 2014

\begin{tabular}{|l|l|l|l|l|l|}
\hline & Films & Single-city & Multi-city & Multi-city film & Total multi- \\
& including at & film & film & productions & city \\
& nationally- & productions & productions & (transnational) & productions \\
& based & production & & & \\
company & & & & & \\
\hline Brazil & $49(12 \%)$ & $20(41 \%)$ & $17(35 \%)$ & $12(24 \%)$ & 29 \\
\hline China* & $111(34 \%)$ & $67(60 \%)$ & $27(24 \%)$ & $17(15 \%)$ & 44 \\
\hline France & $165(41 \%)$ & $75(45 \%)$ & $9(5 \%)$ & $81(49 \%)$ & 90 \\
\hline Germany & $102(25 \%)$ & $13(13 \%)$ & $50(49 \%)$ & $39(38 \%)$ & 89 \\
\hline
\end{tabular}

* Only 331 films were available for the Chinese market in 2013 and 2014.

Sources: www.boxofficemojo.com; www.imdb.com; own research 
Table 2. Degree centrality in four (trans)national film production networks

\begin{tabular}{|l|l|l|l|l|}
\hline Rank & \multicolumn{1}{|c|}{ China } & \multicolumn{1}{|c|}{ Germany } & \multicolumn{1}{|c|}{ France } & \multicolumn{1}{|c|}{ Brazil } \\
\hline 1 & Beijing & Munich & Paris & Sao Paulo \\
\hline 2 & Hong Kong & Berlin & Brussels & Rio de Janeiro \\
\hline 3 & Tokyo $(21.8 \%)$ & $151(12.1 \%)$ & $80(13.8 \%)$ & $28(31.8 \%)$ \\
\hline 4 & $12(5.5 \%)$ & $106(8.5 \%)$ & $32(5.5 \%)$ & $7(8.0 \%)$ \\
\hline 5 & Lew York & Frankfurt & Luxembourg & Madrid \\
\hline 6 & Shenzen & Baden-Baden & Lyon & $6(6.8 \%)$ \\
\hline
\end{tabular}

Note: Table displays degree value for each city, plus the city's percentage share of the total degree value of the network. 


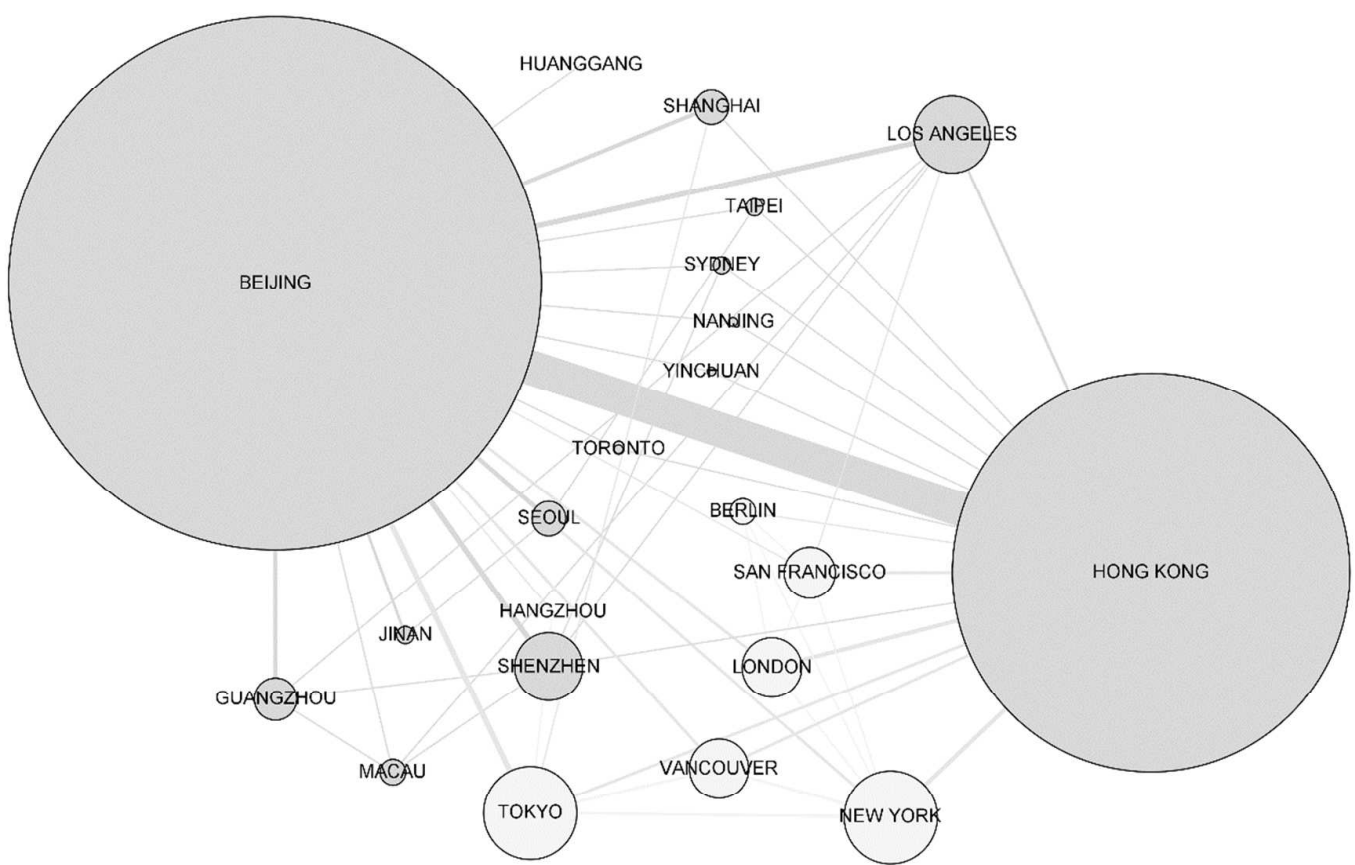

Figure 1 Urban production networks of Chinese film production companies

Note: Node size varies with total number of connections of a given node, edge width varies with total number of connections between two given nodes. 


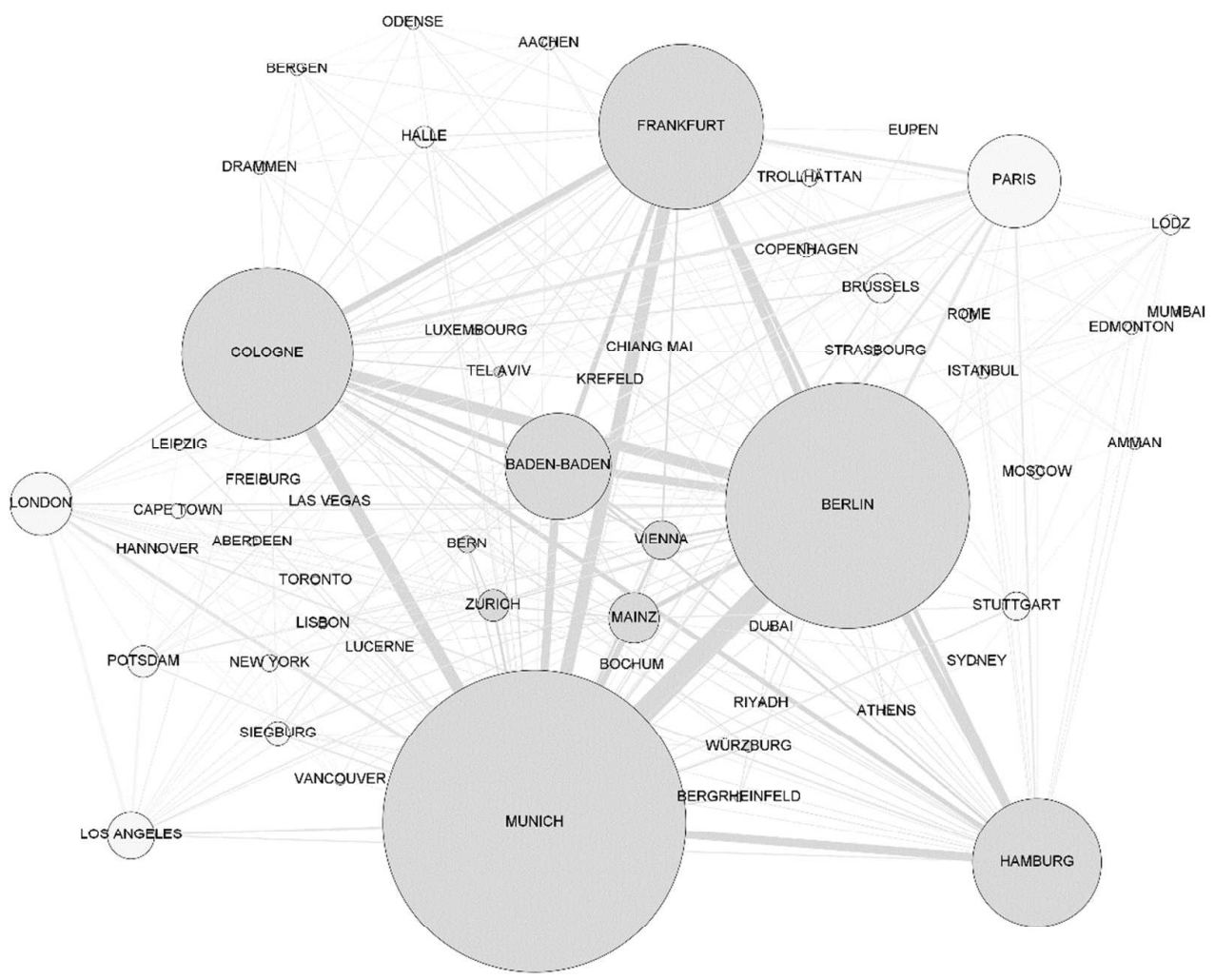

Figure 2 Urban production networks of German film production companies

Note: Node size varies with total number of connections of a given node, edge width varies with total number of connections between two given nodes. 


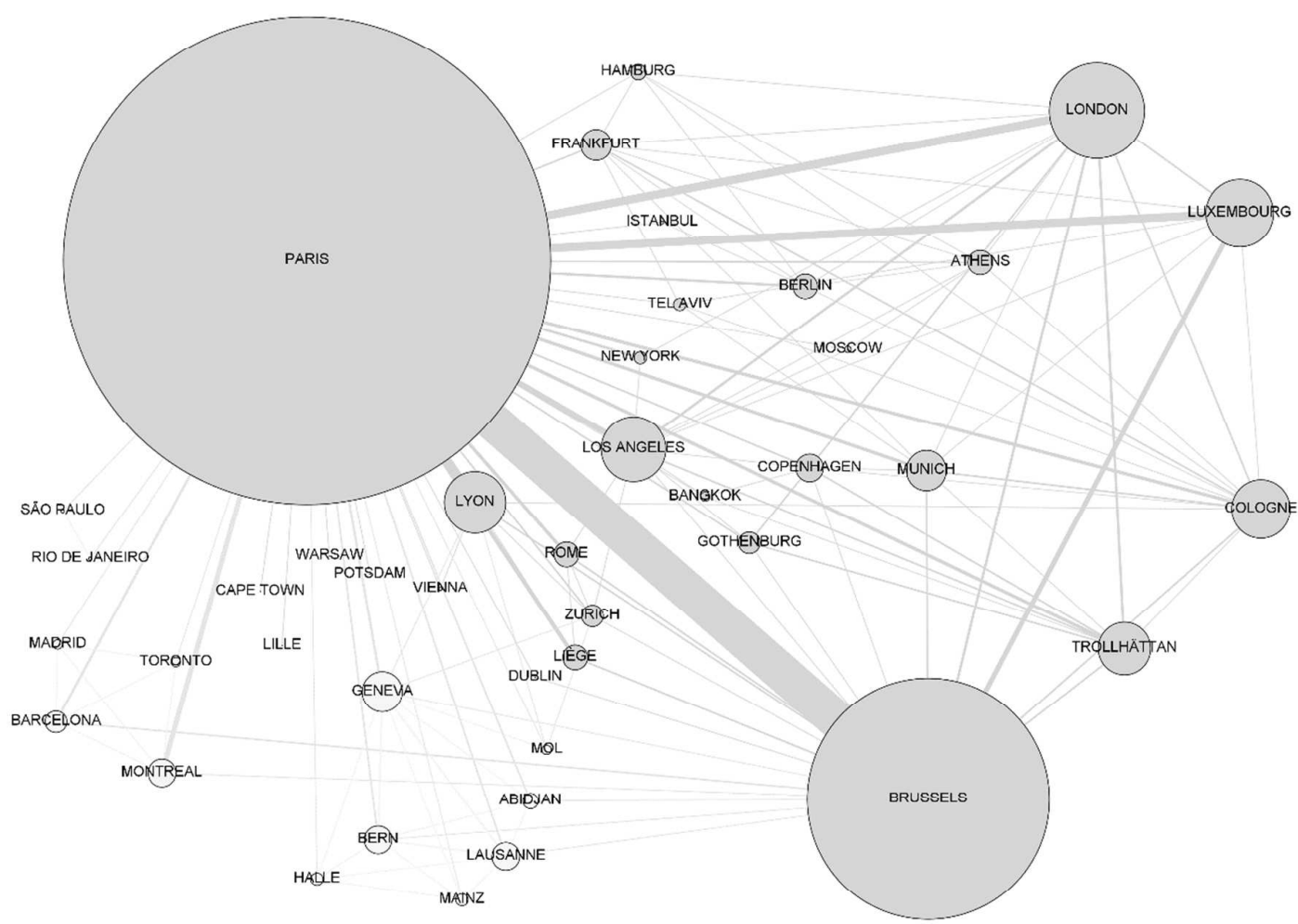

Figure 3 Urban production networks of French film production companies

Note: Node size varies with total number of connections of a given node, edge width varies with total number of connections between two given nodes. 
Figure 4 Urban production networks of Brazilian film production companies

Note: Node size varies with total number of connections of a given node, edge width varies with total number of connections between two given nodes. 